\title{
ANÁLISE COM ÊNFASE NAS RELAÇÕES PRAGMÁTICA E EMOCIONAL NA INTERFACE USUÁRIO X TECNOLOGIA: USUÁRIOS COM MAIS DE 50 ANOS
}

Cahenna Salles Othon Teixeira

Universidade Estadual Paulista - campus Bauru

ka.ichi@hotmail.com

Resumo: Surgida na década de 1920, a televisão é o meio de comunicação com maior número de usuários e tem grande impacto sobre a população brasileira. Embora a TV seja um aparelho indispensável na rotina de muitas pessoas, as complexidades dos modelos mais recentes tornam inviável o pleno uso das diversas funções e possibilidades, principalmente ao público maior de 50 anos. A pesquisa atual tem o propósito de introduzir uma identificação de quais são as principais dificuldades de uso, seus motivos e como o Design poderia melhorar, de fato, a manipulação e a interação do usuário com as novas interfaces, em especial televisores interativos - essa análise deriva de estudos anteriores que indicaram a delimitação do público que apresenta maiores frustrações. Uma vez que a tendência natural é o crescimento do público mais velho, é indispensável considerar os principais pontos a serem melhorados quanto ao uso e compreensão dos aparelhos televisores, reconhecendo como papel do designer solucionar problemas voltados a tais questões. Dessa forma, o propósito é identificar e comprovar as ocorrências a fim de embasar possíveis soluções. Através de pesquisa de campo, analisou-se a relação dos adultos maiores de 50 anos diante dos atuais sistemas de aparelhos televisores, suas funções, opções e pleno uso cotidiano. Por meio de pesquisa bibliográfica, foram observadas questões que envolvem o público alvo, os produtos e o modo de interação proposto pelos objetos estudados. As interfaces exploradas são os aparelhos televisores do tipo digital e smart TVs além de seus respectivos e possíveis controles remotos. Em teste prévio, foi detectado forte receio, o questionário parecia intimidar os participantes, talvez pela forma de abordagem. Por conseguinte, é notório que apenas parte dos entrevistados conhece plenamente as funções e objetivos das novas TVs, bem como as finalidades interativas, assim, não fazem uso além do básico rotineiro por insegurança ou desinteresse em descobrir tantas funções que podem causar confusões posteriormente. É recorrente o fato de que as pessoas atribuem a compreensão moderada à incapacidades ou carências próprias, e não a falhas no projeto. Após aplicação do teste final, foi possível perceber que à medida que se modernizam os aparelhos eletrônicos, mais distantes eles se tornam das pessoas, principalmente adultos avançados. $O$ estudo permitiu perceber o quanto a complexidade de um aparelho influencia o usuário. Para isso fatores como usabilidade, e conceitos de Design Atitudinal são fundamentais durante a elaboração do 
projeto, a fim de que possam evitar além de frustrações, problemas recorrentes, e dificuldades no uso e manuseio das funções das novas TVs.

Palavras-chave: tecnologia, usabilidade, design atitudinal, TV-interativa 